\title{
千里浜海岸における海浜変動の基本特性に関する研究 \\ Basic Characteristics of Shoreline Change and Bar Migration on Chirihama Beach, JAPAN
}

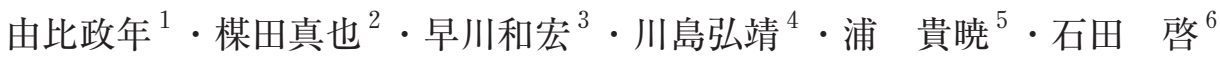 \\ Masatoshi YUHI, Shinya UMEDA, Kazuhiro HAYAKAWA \\ Hiroyasu KAWASHIMA, Takaaki URA and Hajime ISHIDA
}

\begin{abstract}
Basic features of coastal evolution on Chirihama Beach, Japan, have been investigated using a set of field surveys. The results on the shoreline survey show long-term eroding trend during the last twenty years. The cross-shore profile survey records show that the seabed slope has been decreasing more recently. The typical profile configurations are characterized by the presence of multiple bars. An EOF analysis has been conducted on the periodic movements of these bars. The net offshore migrations of bars have been repeated with a return period of approximately 4 years. It is also shown that the transition from double bar to triple bar configuration accompanies the temporal retreat of shoreline. The alongshore variability of the behavior of multiple bar system has also been examined.
\end{abstract}

\section{1.はじめに}

国内外の多くの砂浜海岸は, 重要な観光資源としての 役割を担っている．砂浜での一般車両の走行が可能な 「なぎさドライブウェイ」を有することで知られている 石川県千里浜海岸もその代表的な 1 つであり（石田ら, 1984），春季から秋季にかけて，多くの観光客を魅了し ている．ドライブウェイを安全に維持・管理するために は, 砂浜幅の確保が必要であるが, 千里浜海岸では, 過 去 20 年間で最大約 $50 \mathrm{~m} も の$ 汀線後退が報告されるなど, 浜幅の縮小が顕著である。貴重な観光資源を持続的に発 展させていくためにも，汀線変動を含めた海浜地形変動 の基本特性を把握することは重要である.

千里浜海岸のもう 1 つの特徵として, 大規模な沿岸砂 州の発達をあげることができる（石田ら，1984; 加藤, 1984)。これらの沿岸砂州は, 高波浪時の砕波を促進す ることで, 自然の防波堤として機能し, 広大な砂浜を維 持する上でも重要な役割を担っていると考えられる，近 年の研究により, 著者らは, これらの砂州が, 数年の時 間スケールで変動を繰り返すことを示し（早川ら， 2009 ; Hayakawa et al., 2009), その特性について検討を 行ってきた。しかしながら，砂州移動と汀線位置・土砂 量変動との関連や，平面的な変動モードなど，未解明の 点も多い.

こうした観点から，本研究では，千里浜海岸における 海浜地形変化に関する基礎的研究の一環として, 過去 20

\begin{tabular}{|c|c|c|}
\hline 1 正会員 & 博 (工) & 金沢大学教授環境デザイン学系 \\
\hline 2 正会員 & 博 (工) & 金沢大学講師環境デザイン学系 \\
\hline 3 & 博 (工) & 石川県土木部 \\
\hline 4 学生会員 & & $\begin{array}{l}\text { 金沢大学自然科学研究科博士前期課程 } \\
\text { 石川県土木部 }\end{array}$ \\
\hline 6 フ & 工博 & 金沢大学教授環境デザイン \\
\hline
\end{tabular}

年以上に渡る汀線測量結果㧍よび過去 10 年間の深浅測量 結果をもとに，汀線および等深線位置の変化，沿岸砂州 の形成・移動・消失過程と汀線・土砂量変動との関連, 平面的な変動特性に着目した統計的解析を行う。

\section{2. 対象領域および解析の手法}

\section{(1) 対象領域の概要}

千里浜海岸は, 羽咋市と宝達志水町に跨る押水羽咋海 岸のうち, 能登有料道路今浜ICから羽咋川に続く延長約 $8 \mathrm{~km}$ の砂浜海岸の総称である (図-1 (a)). 石川海岸徳光 地点沖合（水深約 $15 \mathrm{~m}$ ：図-1 (a) 参照) に打ける観測結 果によると，夏期の波浪の多くは有義波高 $1 \mathrm{~m}$ 以下であ り，波向はNNW～NWにやや卓越する. 冬期は有義波 高 $1 \mathrm{~m}$ 以上の高波浪が頻繁に来襲し，波向は $\mathrm{NW} \sim \mathrm{W}$ に 卓越する。年最大有義波高は, $5 \sim 8 \mathrm{~m}$ 程度に達する. 既 往の深浅測量結果（石田ら，1984）より, 海底地形の特 徵を見ると, 水深 $5 \mathrm{~m}$ を心として砂州が 2 段, 3段に発

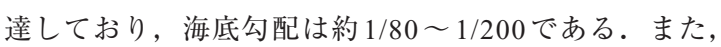
図-1 (b) は，1975年に国土交通省により撮影された航空 写真を合成したものであり，この写真からも大規模な沿 岸砂州の発達が確認できる. 対象領域周辺の汀線近傍に おける代表的な粒径は $0.15 \mathrm{~mm}$ 前後であり，大部分が細 砂である. 千里浜海岸に扔いては, 侵食対策の一環とし て, 1984年以降, 年間 $5,000 \mathrm{~m}^{3}$ 程度の養浜が実施されて いるが，依然として汀線後退が進行中である.

\section{(2) 解析の手法}

本研究では, 石川県土木部河川課による汀線測量結果 （1983～2006年，春季・秋季の年 2 回実施，沿岸方向範 囲約 $15.5 \mathrm{~km}$ ：図-1 (c) 参照) に基づいて, 千里浜㧍よび 周辺海岸に抢ける汀線位置の経年変化・季別変化の解析 を行い，長期的な侵食トレンドや中期的な周期変動特性 


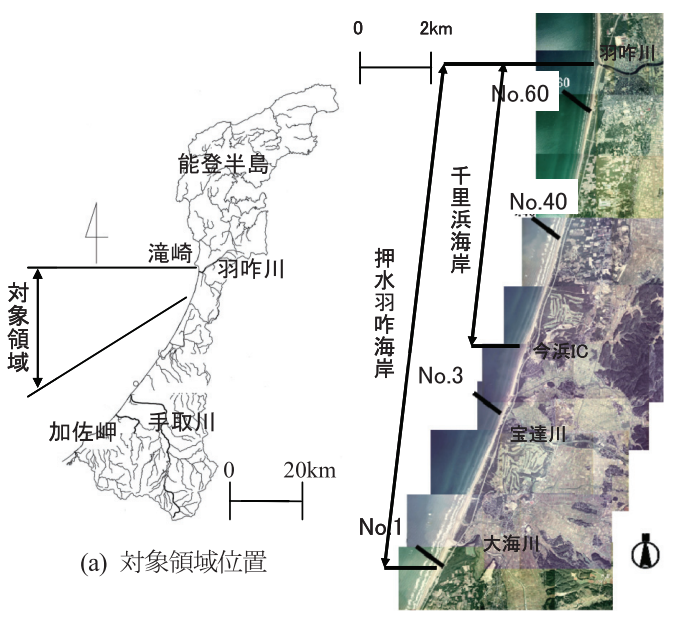

(b) 深浅測量の測線位置

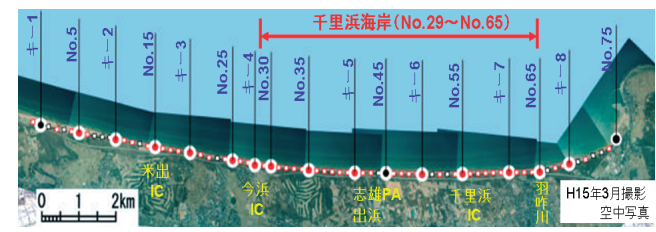

(c) 汀線測量位置

図-1 解析対象領域

について検討を実施した，合わせて，国土交通省金沢河 川国道事務所による深浅測量結果（1998～2007年）を用 いて, 図-1 (b) 中の4測線における等深線位置や土砂量 の変化, 多段砂州の形成・移動・消失過程について比較 検討を行い, 平面的な変動特性についても検討を実施し た。な㧍,深浅測量は，年に 1 回，主に秋季（9１1月） に実施されている，砂州変動に関しては，さらに，経験 的固有関数法により変動の基本モードを抽出し, 土砂量 や汀線位置の中期変動との関連について解析を行った.

\section{3. 汀線および等深線の変動特性}

\section{（1）領域平均された汀線位置の変動特性}

1983〜2006年に石川県土木部河川課により実施された 汀線測量結果に基づき, 春季, 秋季それぞれにおける汀 線変動の特性を検討した。図-2は, 千里浜海岸の測線 (図-1 (c) 中のNo.29 65, 沿岸方向範囲約 $7.2 \mathrm{~km}$ ) で平 均化された汀線変動特性を示している. 観測期間全体で は，春季では $0.67 \mathrm{~m} /$ 年，秋季では $0.46 \mathrm{~m} /$ 年の速度で汀線 が後退しており，長期的トレンドとして，観測期間中に 10-15m程度の浜幅の縮小が見られる. 汀線後退は, 特に, 1980年台後半以降顕著である. 春季・秋季の変動傾向は 類似しているが, 回帰直線の勾配の差が示すように, 季 別変動が徐々に大きくなる傾向がある. また, 汀線変化 には, 長期的後退傾向に加え, 10 年前後の周期的変動が 重畳しており，金沢港，輪島港，德光観測所における波

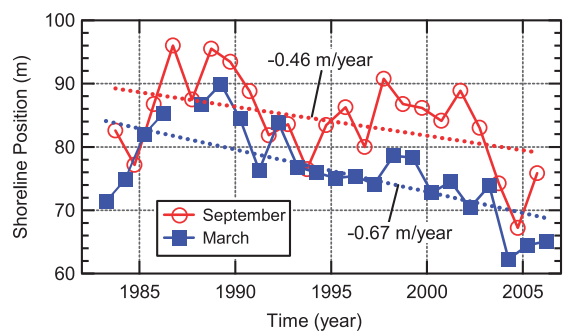

図-2 千里浜海岸の汀線位置変動

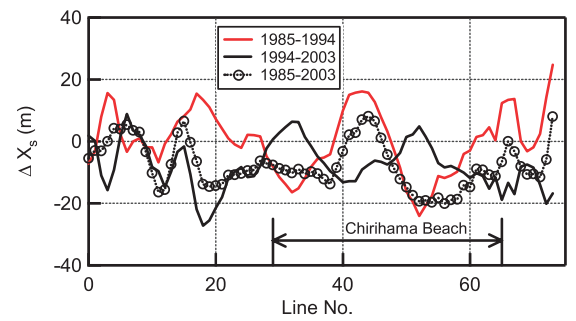

図-3 期間前半・後半 - 全体での汀線位置変化量 (9月測量)

浪観測結果との比較から, 波浪エネルギーの経年変動と 対応することが確認された。トレンドからの偏差は秋季 測量において顕著であり, 最大で $10 \mathrm{~m}$ 程度に達している.

（2）汀線変動の時空間変化

汀線位置の変動特性は一様ではなく，様々な時間的・ 空間的スケールの変化が共存する. 約 4 年サイクルの砂 州変動（早川ら，2009）の影響を除去するために時間方 向に 4 年移動平均を取り, 空間的な局所変動を平滑化す るために隣接 3 測線間の移動平均を取って, 汀線位置の 時空間変化を検討した。移動平均後の解析期間前半 （1985～1994年）・後半（1994年～2003年）打よび通期 （1985～2003年）における汀線位置の変化量について, 沿岸方向変化を解析した例を図-3に示す.なお, 対象領 域北端の滰港近傍は構造物建設の影響で強い堆積傾向を 有するため, それ以外の領域について検討する。期間前 半における汀線位置の変動量を見ると, 汀線後退の顕著 な箇所と堆積傾向の箇所が沿岸方向に交互に現れてい る. 期間後半では, 全体に侵食傾向となるが, ここでも 侵食の顕著な箇所と緩やかな箇所が交互に現れる。期間 後半で汀線後退が顕著となる地点は, 期間前半で汀線が 前進した筒所におよそ対応している. 期間全体を通じて 汀線後退の最も著しい箇所は測線 51 近傍であり, $20 \mathrm{~m}$ 程 度の汀線後退が見られる。測線 43 付近においては, 通期 変動量はプラスとなっているが, 期間後半で侵食の進行 が著しい，全体に，汀線後退の進行速度は時間的に一様 ではなく, 場所によっては, 期間の前半・後半で大きく 変化する。

\section{（3）等深線位置および土砂量の変動}

深浅測量結果に基づいて, 海浜断面内での土砂量の変 

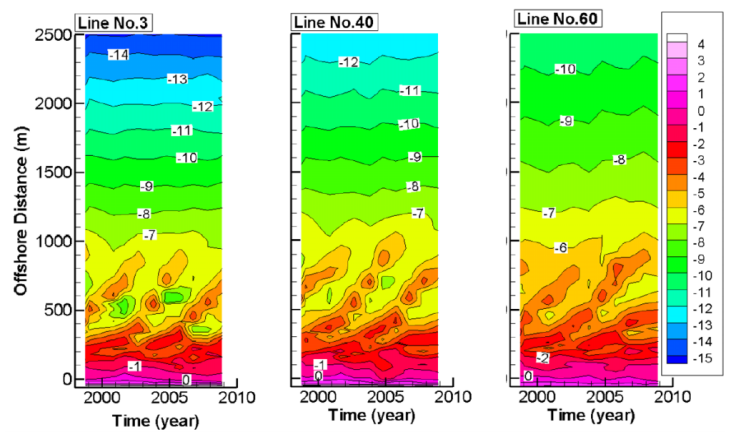

図-4 各測線における地盤高の経年変化

動を算出したところ，横ばいあるいは緩やかに増加する 傾向が見られ，増加傾向は北側の測線ほど強まる結果と なった。この結果は, 汀線近傍と沖合では, 地形変化の 傾向が異なることを示唆しているため, 各測線における 等深線位置の経年変化を解析してみた (図-4)。測線位置 が南側になるほど底面勾配が増加する点は既往の研究と 整合する（石田ら，1984；加藤，1984）。この傾向は, 水深 $7 \mathrm{~m}$ 以上の領域で顕著である。千里浜海岸中央およ び北側に位置する測線 40,60 に着目すると, 汀線付近の 等深線が後退傾向を示すのに対し, 沖側等深線は緩やか に前進しており，断面勾配は減少傾向にある。今回使用 した深浅測量データが 10 年程度と短いため, この傾向が, 今後も継続するかどうか，また，その要因は何か等につ いて，引き続き検討する必要がある。なお，こうした等 深線変化のパターンは, 宇多ら（2008）が, 波向き変動 場に対して示した等深線変動の側方境界付近での挙動に 類似しており，今後の検討に值すると考えられる.

\section{4. 沿岸砂州の時空間変動特性}

\section{（1）測量断面内における砂州の岸沖移動特性}

千里浜海岸における断面地形とその経年変化は, 多段 砂州の存在とその活発な移動により特徵づけられる. 図5 には, 測線 40 を対象に, 断面地形変化を例示した。 上 下図の比較により, 約 4 年サイクルで周期変動が繰り返 されていることが確認できる. 砂州比高（砂州峯高と卜 ラフ底部高の差) の最大值は, $4 \mathrm{~m}$ 以上に達している. 他 の測線に扔ける変動も同様である。このような砂州の周 期的沖向き移動は, オランダ（Ruessink \& Kroon, 1994 ; Winberg \& Terwindt, 1995), ニュージーランド (Shand et al., 1999), 日本 (Kuriyama, 2002), 米国など, 世界各地 (Shand et al., 1999など) で報告されている移動形態（Net Offshore Migration）と共通である.

近隣の石川海岸においても砂州の周期的変動が見られ る. 両者には, 砂州移動の最終段階に特徽的な相違点が 存在し, 石川海岸に扔いては砂州が岸向きに移動して減 衰する（由比, 2008）のに対し, 千里浜海岸では砂州は
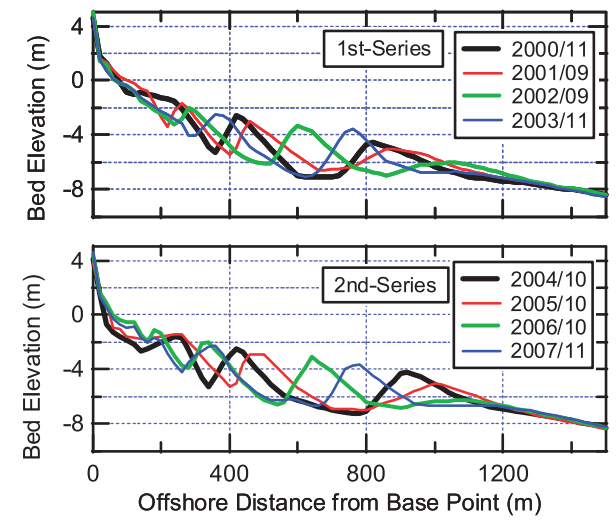

図-5 砂州の周期的移動の例（測線 40）

沖向きに移動・消失していく. 砂州の減衰・消失段階に おける, 変動パターンのこのような相違は国外の報告例 でも見受けられる (Shand, 1999).

\section{(2) 経験的固有関数法による解析}

実数型の経験的固有関数法（EOF）（例えば, Winant ら，1975）を適用し, 沿岸砂州の周期的変動に寄与する 特徵的モードを抽出してみた。経験的固有関数法では, 測量結果の地盤高を複数の固有モードの重ねあわせで表 現する.ここで, 変動に対する寄与率の大きい順に第 1 モード，第2モードと順位付けを行う。個々の固有モー ドは, 時間の関数である時間係数と, 空間の関数である 固有関数の積の形に変数分離され, 海底地形の時空間変 動は以下のように表現される.

$$
h_{i k} \approx \sum_{n=1}^{N} C_{n k}(t) e_{n i}(x)
$$

ここで, $h_{i k}$ は, $i$ 番目の測点における $k$ 回目の深浅測量 時の地盤高を表す. また, $e_{n i}$ は測点 $i$ の位置における第 $n$ モードの固有空間関数, $C_{n k}$ は $k$ 回目の調査における第 $n$ モードの時間係数である．岸沖方向における測量実施間 隔は不均一であるため, 線形補間を用いて, 地盤高デー 夕（T.P.）を等間隔 $(20 \mathrm{~m})$ に再配置した。以下では, 朔望平均干潮位（T.P. $+0.01 \mathrm{~m}$ ）を基準とした期間平均汀 線位置を基準として離岸距離を表す．EOF解析の対象区 間は, 離岸距離-60m 地点から沖合 $2500 \mathrm{~m}$ 地点の範囲であ るが, 以下では, 水深変化が比較的明瞭に現れる $1300 \mathrm{~m}$ 地点までの範囲を図示する。なお, EOF解析の適用に際 して, 測量地盤高から期間平均地盤高を差し引いた残差 分を対象とすることが多いが, 本研究では, 土砂量変動 と砂州移動のモードを分離することを意図して，地盤高 データ自身に対して経験的固有関数法を適用した.

まず，地形変動の中核となる上位 3 モードについてそ の特徵を抽出するとともに, 土砂量変動との関連を検討 した. 図-6から図-9は, 測線 40 に対する実数型経験的固 
有関数法の解析結果である. 他の測線に対する解析結果 も同様である.第 1 モードの時間係数 $C_{1}$ （比較のため - 1 倍して表示) は, 沿岸漂砂の不均衡等に起因する海浜断 面積の変動 $\Delta S$ （1998年基準, 単位幅あたりの土砂量変 化に相当）と良く対応している.この測線においては, 前述のように, 等深線が汀線付近で後退, 沖側で前進傾 向にあり, 断面内土砂量としては僅かな増加傾向にある. $C_{1}$ は, 振動的に変化しつつ全体に減少（図中では符号反 転表示のため右上がり）しており，空間関数 $e_{1}$ （観測期 間中の平均地形に対応する. 図-8 (a) 参照) との積で考 えると，この傾向と符合する. 第 2,3 モードの時間係数 は，位相が互いに約 $1 / 4$ 周期ずれた形となる（図-7）. 空 間係数についても同様（図-8 (b)）であり，この組み合わ せで砂州の周期変動に対応する. 図-9は, 第2,3モードの 重ね合わせを示す. 砂州の沖向き移動が約 4 年のサイク ルで繰り返されること, 個々の砂州の形成・移動・消失 の過程はおよそ 8 年程度の期間に渡ることなどが良く再 現されている. また, この砂州移動モードは, 断面内に おける土砂の岸沖方向の分配には寄与するが, 断面全体 としての土砂量増減への影響は小さいことも確認された.

次に, 砂州移動と汀線変動との関連について検討した. 図-8の空間関数の分布より, 第3モードは2段砂州の配置 に，第2モードは3段砂州の配置にそれぞれ対応するこ とが見て取れる。前述のように, 両モードの時間係数は 位相が $1 / 4$ 周期ずれた形となっているため, 第 2 モードが 卓越する $\left(C_{2}\right.$ の值が大きくなる $)$ 時点においては, 第3モ ードの影響は小さく（C 3 が小さく）なる。この結果, 図-5からもわかるように，たとえば，第3モードの卓越 する2003年11月においては, 砂州は2段配置となるのに

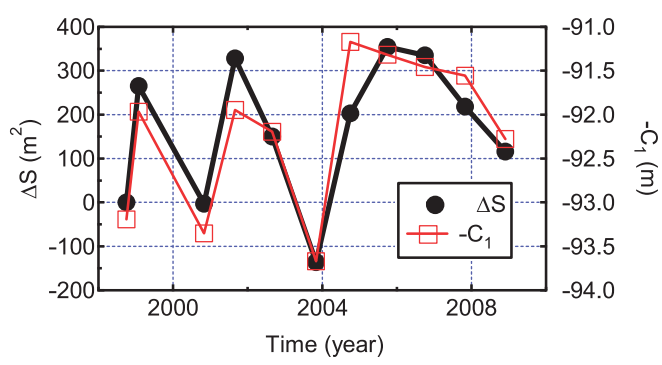

図-6 第 1 モード時間係数と海浜断面積（測線 40）

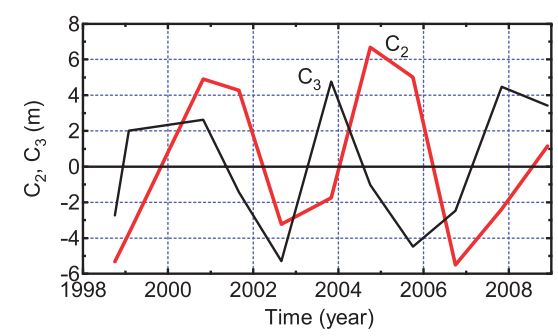

図-7 第 2, 第3モードの時間係数（測線 40）
対し, 第2モードが卓越する 2004 年 10 月には, 砂州は 3 段配置へと変化する. 空間関数 $e_{2}$ の分布を見ると, $C_{2}$ が 極大となる時点では, $200 \mathrm{~m}$ 付近に 3 段目の砂州が形成さ れる。一方, それより岸側の $e_{2}$ が負となる領域では地盤 高が低下し, 汀線が後退する（たとえば, 図-2や図-5に おいて，2004年10月には汀線が後退している).すなわ ち, 砂州配置の変動は, 断面内の土砂総量には影響を与 えないが, 岸沖方向の土砂量バランスを変化させ, 汀線 位置の中期的変動を誘起し得る. 図-2の秋季の変動にお いて, 汀線が前進した後に 3 年間後退するという形が繰 返し現れている.これは 4 年サイクルでの砂州変動の影 響もその一因と推測される. 以上の結果は, 千里浜海岸 のような大規模な砂州の発達と時間変化を特徵とする海 岸においては, 汀線位置の変動だけから（断面形の平行 移動を仮定して）土砂量の変動を推定することは困難で あることを示しており, 注意が必要である.

\section{（3）沿岸砂州の平面的な変動特性}

次に, 4 測線の測量結果を比較して, 沿岸砂州の平面

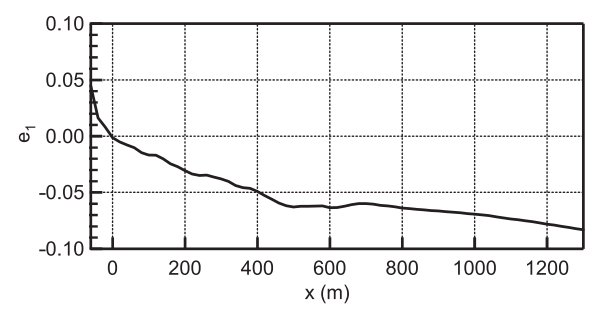

(a) 第 1 モード

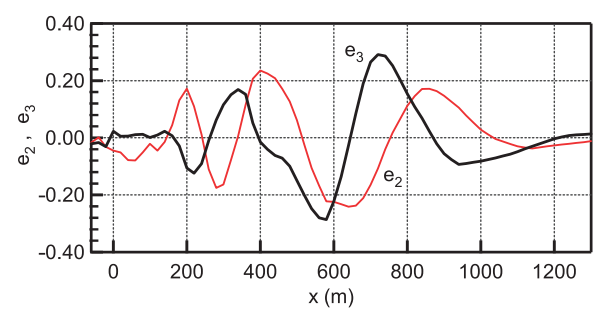

(b) 第 2,3 モード

図-8 空間係数（測線 40)

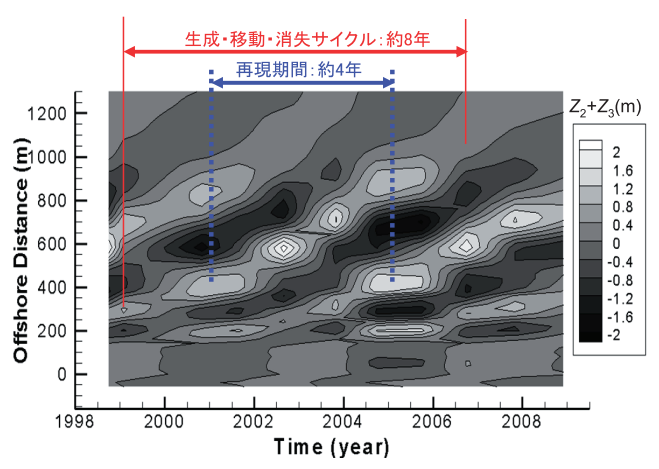

図-9 第2,第3モードの重ね合わせ（測線 40） 


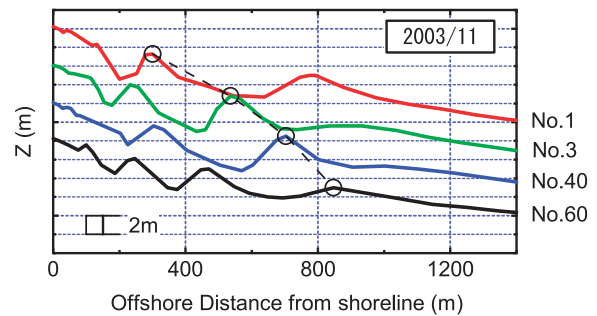

図-10 4 測線の断面地形の比較例（2003年）

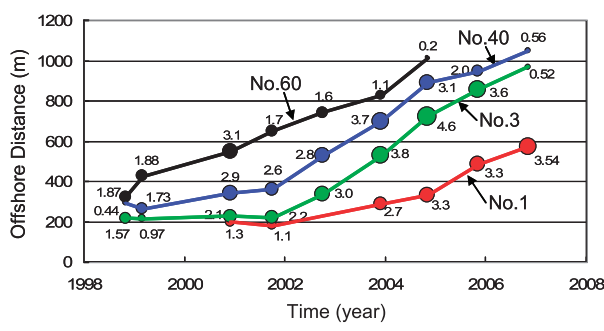

図-11 各測線における砂州頂部移動の比較例 (円の大きさは砂州比高に比例)

的な形状および変動特性を解析した。図-10は，同時点 における4測線の断面地形の比較例である。なお，沿岸 方向に連続する砂州の頂部位置を例示するために, 後述 の図-11 に対応するものを丸印と破線で繋いで示した. この時点では, 各測線において，3段から4段の砂州が確 認されるが，いずれの段に扔いても，南側に向かうにつ れ，汀線から砂州頂部までの離岸距離が小さくなる。つ まり，平面的に見ると，砂州は汀線に対して緩やかに湾 曲する弓なりの形状を描いており，前述の海底勾配変化 と対応する．図-10に扔いて測線1で最沖に位置する砂州 は, 測線3では減衰し, さらに北側の測線 40 及び 60 では 消失している，逆に，測線60で沖から 3 番目に形成され ている砂州は，測線 40 以南では発達が不十分である. 図-10で印をつけた砂州に着目し，4測線における頂部位 置の経年変化を解析した例を図-11に示す．図中の数值 は砂州比高（砂州頂部高とトラフ底部高の差）を表す。 北側の測線から南側に向けて砂州移動が伝播していく様 子が見て取れる，以上まとめると，沿岸砂州は，南側ほ ど汀線に近く，その移動に際しては，汀線に対して緩や かな弧状を保ったまま全体に沖向きに移動し，北側から 順に消失していると考えられる。

\section{5. おわりに}

本研究では, 千里浜海岸周辺の海浜変形に関する研究 の一環として, 汀線および沿岸砂州の変動特性について 現地測量デー夕に基づく検討を行った。過去 20 年以上に 渡る汀線測量結果から，長期的な侵食傾向と中期的な変 動が共存することが確認された．過去 10 年の深浅測量結
果からは, 汀線近傍の等深線が後退する一方, 沖合の等 深線は前進し，海底勾配が緩勾配化する傾向が見られた。 また，砂州の沖向き移動が約 4 年のサイクルで繰り返さ れ, 砂州の形成 ・移動・消失過程は 8 年程度の期間に渡 ることが示された．沿岸方向については，砂州は南側に 位置するほど汀線に近づき，北側から南側へと砂州の移 動が伝播していくことが確認された．経験的固有関数法 による解析結果は，海浜地形変動の基本モードの特徵を 良く抽出しており，砂州変動モードは，土砂総量の変化 には寄与しないが，岸沖方向の配分を変化させることで， 中期的な汀線変動を誘起し得ることを示した.

謝辞：本研究で使用した測量デー夕は，国土交通省北陸 地方整備局金沢河川国道事務所抢よび石川県土木部河川 課より提供いただいた。また，本研究の一部は，日本学 術振興会科学研究費補助金の補助を受けた。千里浜海岸 研究会における，日本大学・熟見浩一准教授，金沢大 学・斎藤武久准教授との議論からは, 有益な示唆をいた だいた。ここに記して謝意を表する。

\section{参 考 文 献}

石田 啓・高瀬信忠・長原久克・浦 良一（1984）：渚ドライ ブウェーを有する千里浜海岸の現況と侵食対策，第 31 回 海岸工学講演会論文集, pp.355-359.

宇多高明・熊田貴之・芹沢真澄・長山英樹（2008）：波向変動 場で生じる漂砂大循環の発生メカニズム，海岸工学論文 集，第 55 巻, pp.506-510.

加藤一正（1984）：長周期波と多段砂州の成因について，第31 回海岸工学講演会論文集, pp.441-445.

早川和宏・由比政年・石田 啓 (2009) : 石川県千里浜海岸に おける沿岸砂州の変動に関する基礎的研究，海洋開発論 文集，第25巻, pp.1197-1201.

由比政年（2008）：石川海岸における沿岸砂州の長期・広域変 動に関する基礎的研究, 海岸工学論文集, 第 55 巻, pp.596-600.

Hayakawa, K., M.Yuhi, and H.Ishida (2009) : Migration of multiple sandbars on the Chirihama Beach, JAPAN, Proceedings of Coastal Dynamics 2009, in CD-ROM, Paper No.140, pp.1-11.

Kuriyama, Y. (2002) : Medium-term bar behavior and associated sediment transport at Hasaki, Japan. J. Geophysical Res., Vol. 107, No. C9, 3132, doi:10.1029/2001JC000899.

Ruessink, B. G., and A. Kroon (1994) : The behaviour of a multiple bar system in the nearshore zone of Terschelling, the Neterlands: 1965-1993, Marine Geology, Vol. 121, pp.187-197.

Shand, R. D., D. G. Bailey, and M. J. Shepherd (1999) : An Inter-site comparison of net offshore bar migration characteristics and environmental conditions, J. Coastal Res., Vol. 15, No.3, pp.750-765.

Wijnberg, K.M. and J.H.J. Terwindt (1995) : Extracting decadal morphological behavior from high-resolution, long-term bathymetric surveys along the Holland coast using eigenfunction analysis, Marine Geology, Vol.126, pp. 301-350.

Winant, C. D., D. L. Inman, and C. E. Nordstrom (1975) : Description of seasonal beach changes using empirical eigenfunctions, J. Geophysical Res., Vol. 80, No. 15, pp.19791986. 